\title{
Development and regulation of pancreatic juice secretion in cattle. State-of-the-art ${ }^{*}$
}

\author{
Dedicated to Professor Wieslaw Barej (1934-2000)
}

R. Zabiclski ${ }^{1,2}$ and S.G. Pierzynowski ${ }^{3,4}$

'Department of Physiology, Biochemistry, Pharmacology and Toxicology, Faculty of Veterinary Medicine, Warsaw Agricultural University Nowoursynowska 166, 02-787 Warsaw, Poland

'The Kielanowski Institute of Animal Physiology and Nutrition, Polish Academy of Sciences 05-110 Jablonna, Poland

${ }^{3}$ Department of Animal Physiology, University of Lund

22362 Lund, Sweden

${ }^{4} R \& D$ Gramineer International $A B$, Ideon

22370 Lund, Sweden

(Received 18 August 2000; accepted 22 January 2001)

\begin{abstract}
The secretion of pancreatic juice was studied in cattle from the first days of life to the start of numination and in adult cows. Synchronized periodic oscillations of pancreatic secretion in phase with the duodenal migrating motor complex were observed in calves from $2^{\text {nd }}-3^{\text {rd }}$ day of life. These pancreatic oscillations developed with the maturation of the gastrointestinal tract. In adult cattle, pancreatic secretion was relatively stable and essentially did not respond to feeding. However, manipulation of the diet effectively changed daily exocrine secretion, and it is hypothesized that the insulo-acinar axis may be important in this respect. The importance of the vagal nerves, gastrointestinal regulatory peptides, and duodenal contents in the regulation of pancreatic secretion in young and adult cattle is discussed. Some gastrointestinal regulatory peptides affect the pancreas indirectly from the site of their release, i.e., the proximal duodenum in preruminant calves. Vagal extrinsic innervation appears to play a critical permissive role in the effect of gastrointestinal regulatory peptides on the exocrine pancreas.
\end{abstract}

KEY WORDS: calf, development, regulation, duodenum, gut regulatory peptides, vagal nerve, weaning

\footnotetext{
* Supported by the State Committec for Scientific Research, Grant No 5 P06K 00716

' Corresponding author
} 


\section{ABBREVIATIONS}

BW, body weight; CCK, cholecystokinin; 4-DAMP, 4-diphenylacetoxy-N-methylpiperidine-methiodide, a $\mathrm{M}_{3}$ muscarinic antagonist; $\mathrm{DCD}$, diversion of duodenal contents; GDCD, diversion of gastric and duodenal contents; GI, gastrointestinal; $\mathrm{HCl}$, hydrochloric acid; ISA, irregular spiking activity = phase 2 of $\mathrm{MMC}$; iv, intravenous; $\mathrm{MMC}$, migrating myoelectric complex; NSA, no spiking activity = phase 1 of MMC; PPS, periodic pancreatic secretion; PACAP, pituitary adenylate cyclase-activating polypeptide; PP, pancreatic polypeptide; RSA, regular spiking activity = phase 3 of MMC; SPM, spikes per minute; U, units; VIP, vasoactive intestinal peptide

\section{INTRODUCTION}

The exocrine pancreas produces a number of digestive enzymes, including proteases, lipases, amylase, and nucleases important for the degradation of nutrients in the small intestine. The mixture of electrolytes in the pancreatic juice provides an optimal environment for these enzymes. There is little information available about the mechanisms controlling the synthesis and secretion of pancreatic juice in ruminants in comparison with that available for monogastric animals. However, understanding these mechanisms in ruminants is important, especially since the proper manipulation of pancreatic secretion may improve the enzymatic degradation of animal feed and thus possibly reduce loss of nitrogen to the environment. Even less is understood about the controlling mechanisms of pancreatic juice secretion in young ruminants, before and around weaning.

In the preruminant calf, the forestomachs are under development and the fermentation processes in the rumen do not function (Ruckebusch et al., 1983), thus the pancreas appears to play a key role in feed digestion, and its function is probably as important for the young ruminant as it is for monogastric animals. However, the information obtained from research on monogastric animals may not be transferable to preruminant calves. Therefore, it is essential to evaluate characteristics of exocrine pancreas function in these young animals. A summary of the results obtained in our laboratories with respect to pancreatic secretion and its regulation in calves, adult cattle and sheep is presented in the following sections.

\section{ANIMAL MODELS}

For the studies of exocrine pancreas regulation and function, the method of Routley et al. (1952) with further modifications (Pierzynowski and Barej, 1984; 
Picrzynowski et al., 1988; Zabielski et al., 1992) was used. This method was based on the direct catheterization of the accessory pancreatic duct that leads the major portion of pancreatic juice out into the duodenum in cattle (Wass, 1965), and cannulation of the duodenum for the reintroduction of pancreatic juice between the experiments. The advantages and limitations of this method have been discussed previously (Pierzynowski et al., 1995; Kato et al., 1999). The experiments started 4-5 days after surgery. During the collection of pancreatic juice the animals were kept in individual cages. The collected juice was infused into the duodenum by means of a peristaltic pump after a $0.1-0.2 \mathrm{ml}$ juice sample was taken for analyses. Most of the pancreatic catheters functioned successfully for up to 2 months and in some calves for more than 3 months; therefore it was possible to observe all the dynamic changes in pancreatic secretion during development in the same animal (Pierzynowski et al., 1991). In adult cattle, the catheters functioned for up to 6 months, while in sheep for 2 months.

For studies involving the electrical activity of the GI tract, calves were surgically equipped with bipolar silver electrodes and strain gauges (Zabielski et al., 1993 ) sutured just posterior to the duodenal bulb and anterior to the orifice of the pancreatic accessory duct. Sometimes two more electrodes were prepared instead of the strain gages, and the electrodes were sutured posterior to the orifice of the pancreatic accessory duct and on the proximal jejunum. The electrodes were connected to bioelectric amplifiers, and the strain gauges were connected to isometric amplificrs that were coupled to an analog digital converter and computer (Figure 1). The phases of small intestinal migrating myoelectric complexes (MMC) were identified according to Ruckebusch (1989). In order to perform perfusion studics, additional cannulae were implanted in the duodenum $1 \mathrm{~cm}$ distal to the duodenal bulb and in the abomasum. To study the effect of the infusion of regulatory peptides into the local duodenal circulation, silicone catheters were implanted into the right gastroepiploic artery. In acute experiments it was confirmed that the infused peptides did not reach the pancreas directly (Zabielski et al., 1994). The left and right cervical vago-sympathetic trunks were prepared with cooling devices (Podgurniak, 1987) in some of operated preruminant calves to determine the effect of vagal cold blockade on pancreas function (Zabielski et al., 1990, 1992).

\section{DEVELOPMENT OF PANCREATIC FUNCTION}

\section{Pancreatic secretion in preruminant calves}

It was observed that before the morning milk feeding, young preruminant calves (1 week of age) secreted approximately $0.5 \mathrm{ml} / \mathrm{kg}$ pancreatic juice per $\mathrm{h}$ (Pierzynowski et al., 1991). The secretion doubled the preprandial levels during 


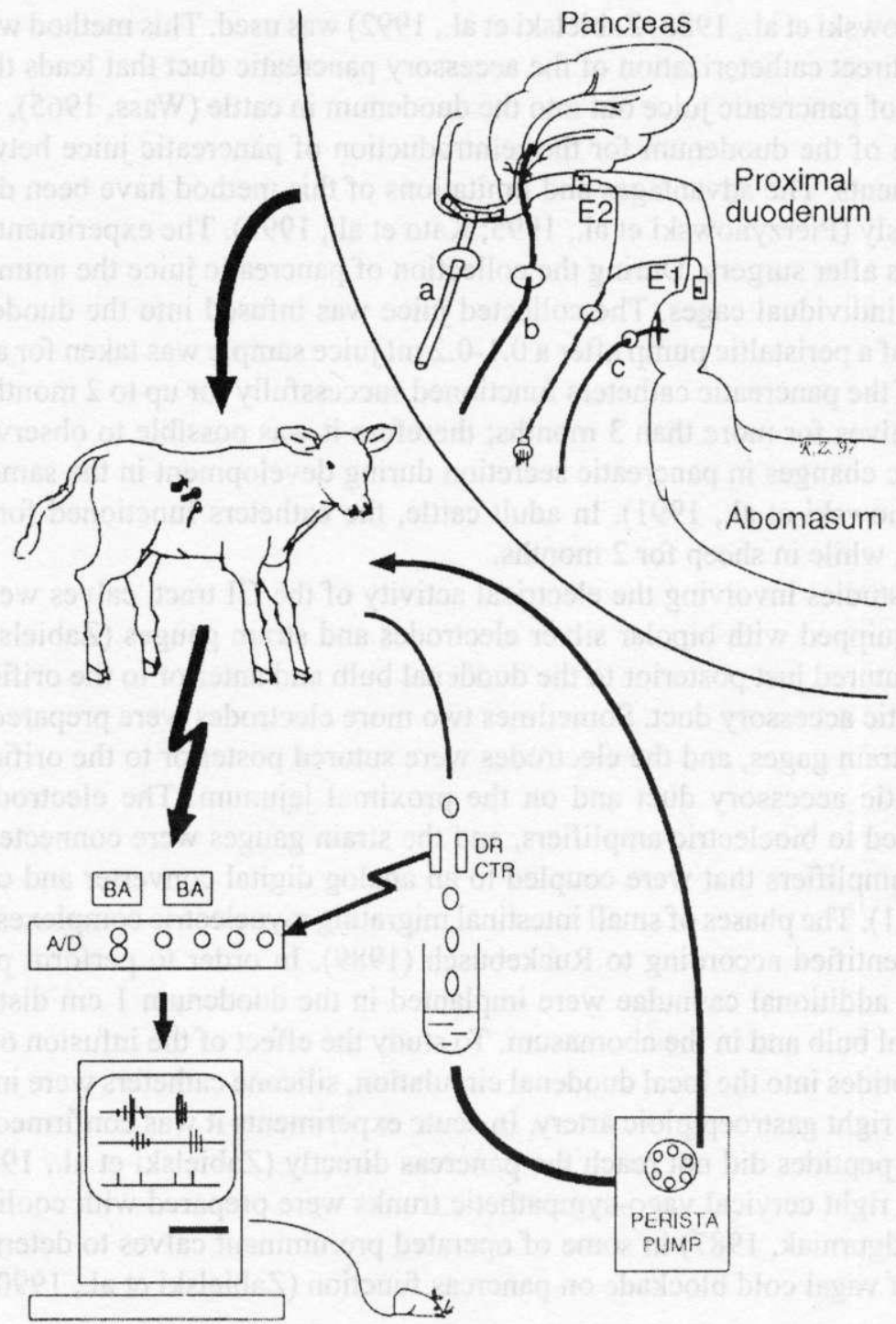

Figure 1. Model used for investigation of a synchronised pancreatic juice secretion and duodenal myoelectrical activity. Surgical model (right top): calves were implanted with (a) duodenal T-cannula for reintroduction of pancreatic juice, (b) accessory pancreatic duct catheter for pancreatic juice collection, (c) duodenal bulb catheter for intraduodenal infusions, and (E1, E2) serosal bipolar electrodes. Electromyography and pancreatic secretion recording: electrode extension cables were connected to computerised data acquisition system for electromyography recording, and pancreatic catheter was connected to a photoelectric drop counter (DR CTR) for continuous recording of pancreatic juice flow. Pancreatic juice after taking a small sample for protein and enzyme analysis was infused into the duodenum with a peristaltic pump 
and up till 15 min after milk consumption, and decreased thereafter (Figure 2). The subsequent volume of the postprandial secretion tended to be smaller than that of the preprandial, which has also been observed in older preruminant calves (McCormick and Stewart, 1967; Ternouth and Buttle 1973; Toullec et al., 1994) as well as in adult cattle and sheep (Figure 2). It was suggested that this observation may be related to a rapid increase in the duodenal $\mathrm{pH}$ due to the arrival of large amounts of milk or to decreased vagal input after the ingestion of feed. Indeed, plasma concentration of PP, an established marker of vagal tone, has been shown to significantly decrease after feeding in preruminant calves (Toullec et al., 1992; Zabielski et al., 1998). The other reason could be a limited secretory capacity of the exocrine pancreas in newborns. Intravenous 1 -h continuous infusion of a pharmacological dose of CCK-8 $(120 \mathrm{pmol} / \mathrm{kg} / \mathrm{h})$ produced stimulation of pancreatic juice to half of that following milk feeding. The stimulation was observed, however, during the first $30 \mathrm{~min}$ postinfusion and then the secretion dropped despite stimulation (Zabielski et al., 1995). For the period of milk consumption and for the subsequent $15 \mathrm{~min}$, pancreatic protein output tripled from its preprandial level of $2.5 \mathrm{mg} / \mathrm{kg} / \mathrm{h}$, and trypsin activity more than tripled from its preprandial value of $30 \mathrm{U} / \mathrm{kg} / \mathrm{h}$. This increase in pancreatic secretion during and just after feeding reflected the cephalic stimulation of the exocrine

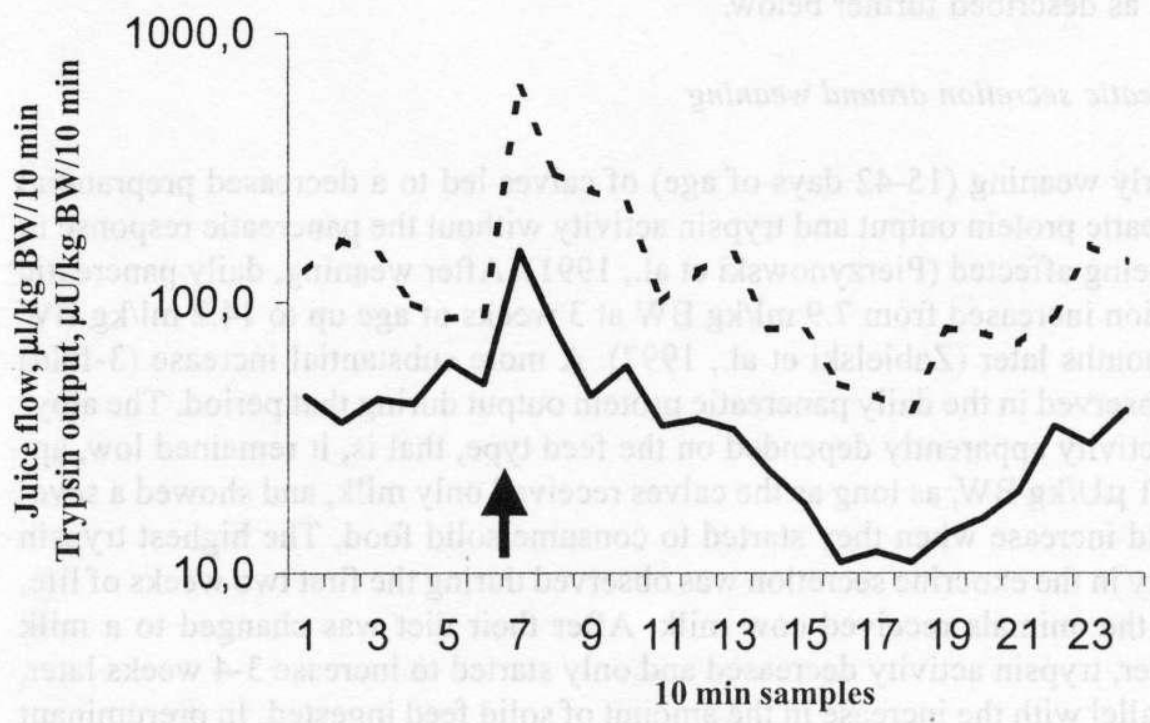

Figure 2. Mean secretion of pancreatic juice (juice flow - trypsin output - - - ) in five calves $6 \mathrm{~d}$ old. Note, presence of cephalic phase during suckling (arrow) and lack of gastric and intestinal phase elevation, instead a reduction of secretion below the preprandial level is observed 
pancreas (see below). Surprisingly, there was no difference between the preprandial and postprandial protein outputs or trypsin activities (Pierzynowski et al., 1991), which is in contrast with results obtained in dogs and human pancreas studies.

In comparison with the effect of feeding cow milk, feeding calves a commercial milk replacer (containing milk powder, soyabean and fish meal) evoked even more potent stimulation of exocrine pancreas sccretion. This stimulation lasted for approximately $30 \mathrm{~min}$, suggesting that a portion of the pancreatic response may depend on factors present in the feed (e.g. soya bean protein). On the other hand, suppression of pancreatic secretion by milk feeding could also be possible due to an opioid effect of hydrolyzed casein fragments, as has been shown for gastric suppression in suckling neonatal rats (Rao et al., 1995). Therefore, the pancreatic response to milk or to milk replacer might differ according to protein composition and the presence of certain biologically active substances in cow milk and milk replacers of different origin (Xu, 1998; Zabielski, 1998). Nevertheless, neither the classical gastric phase nor the intestinal phase of pancreatic juice secretion were observed in preruminant calves (Pierzynowski et al., 1991; Zabielski et al., 1997) in any of our experiments, as has been reported for monogastric animals (Konturek et al., 1986; Chey, 1991). Short lasting elevations in pancreatic juice flow and trypsin activity before and after suckling present in Figure 2 are due to a periodic activity of the pancreas associated with duodenal MMC as described further below.

\section{Pancreatic secretion around weaning}

Early weaning (15-42 days of age) of calves led to a decreased preprandial pancreatic protein output and trypsin activity without the pancreatic response to feed being affected (Pierzynowski et al., 1991). After weaning, daily pancreatic secretion increased from $7.9 \mathrm{ml} / \mathrm{kg} \mathrm{BW}$ at 3 wceks of age up to $14.2 \mathrm{ml} / \mathrm{kg} \mathrm{BW}$ two months later (Zabielski et al., 1997). A more substantial increase (3-fold) was observed in the daily pancreatic protein output during that period. The amylase activity apparently depended on the feed type, that is, it remained low, approx, $1 \mu \mathrm{U} / \mathrm{kg} \mathrm{BW}$, as long as the calves received only milk, and showed a several-fold increase when they started to consume solid food. The highest trypsin activity in the exocrine secretion was observed during the first two weeks of life, when the animals received cow milk. After their diet was changed to a milk, replacer, trypsin activity decreased and only started to increase 3-4 weeks later, in parallel with the increase in the amount of solid feed ingested. In preruminant calves fed only milk replacer for 45 days, the amount of pancreatic secretion and protein output calculated per $\mathrm{kg} \mathrm{BW}$ did not change during the entire experimental period (Zabielski et al., 1994), in comparison with that of weaned calves. 


\section{Food and pancreatic secretion in adult cattle}

Cows fed with grain concentrate and hay showed only slight variations in pancreatic secretion that were independent of feeding (Figure 3), and secreted a daily average of $13.9 \mathrm{ml} / \mathrm{kg} \mathrm{BW}$ pancreatic juice and $0.09 \mathrm{~g} / \mathrm{kg} \mathrm{BW}$ total protein (Pierzynowski et al., 1988), similar to the secretion observed in weaned calves. After enriching the cow dict with light fermented carbohydrates (maintaining an energy intake and total protein similar to those in the standard diet), the daily exocrine flow increased up to $21.9 \mathrm{ml} / \mathrm{kg} \mathrm{BW}$, but the protein output $(0.12 \mathrm{~g} / \mathrm{kg} \mathrm{BW})$ was not significantly affected. In addition, the activity of pancreatic amylase, trypsin and chymotrypsin did not differ significantly between the two diets. In another study, it was observed that fasting for $48 \mathrm{~h}$ (with free access to water) decreased both the exocrine secretion and plasma insulin concentration in the adult cow (Pierzynowski, 1990; Figure 3). Following this period, a $24 \mathrm{~h}$ intraduodenal infusion of glucose normalized both pancreatic functions (juice secretion and insulin concentration). The data suggested that a possible insulin-dependent mechanism affected the regulation of the exocrine pancreas in ruminants. This hypothesis was supported by the results obtained in sheep that had alloxan-induced diabetes (Pierzynowski and Barej, 1984; Pierzynowski et al., 1986). In the diabetic state, the volume of pancreatic juice decreased markedly and returned to the initial value after insulin treatment. The daily secretion of lipase and amylase also decreased during diabetes, and insulin treatment restored the secretion of lipase but not amylase. In control sheep, vagal stimulation increased the juice flow, protein content and plasma insulin concentration. In diabetic animals, vagal stimulation had no effect on volume and resulted in only a slight increase in the exocrine protein content and plasma insulin concentration (Pierzynowski et al., 1986). These findings suggested that insulin and vagal innervation in ruminants are very important factors for direct regulation of exocrine pancreas secretion. Mineo et al. (1995) showed that CCK may also be involved indirectly regulating this secretion via insulin.

\section{Cephalic stimulation of pancreatic secretion}

It was shown that milk was a weak stimulant of pancreatic secretion in preruminant calves (Pierzynowski et al., 1991). When the calves suckled milk, the exocrine juice secretion showed a brief increase. Apparently, this increase was due to the effect of cephalic stimulation, since it could be blocked by atropine (muscarinic non-specific receptor blocker) or cold vagal blockade (Picrzynowski ct al., 1992), and by a muscarinic $M_{3}$ specific receptor blocker, 4-DAMP (Leśniewska et al., 1996). Moreover, a similar cephalic phase was observed after giving an empty feeding-bucket to the calf to suckle for couple of minutes (Leśniewska and Zabielski, unpublished data). Intraduodenal administration of CCK-A receptor antago- 

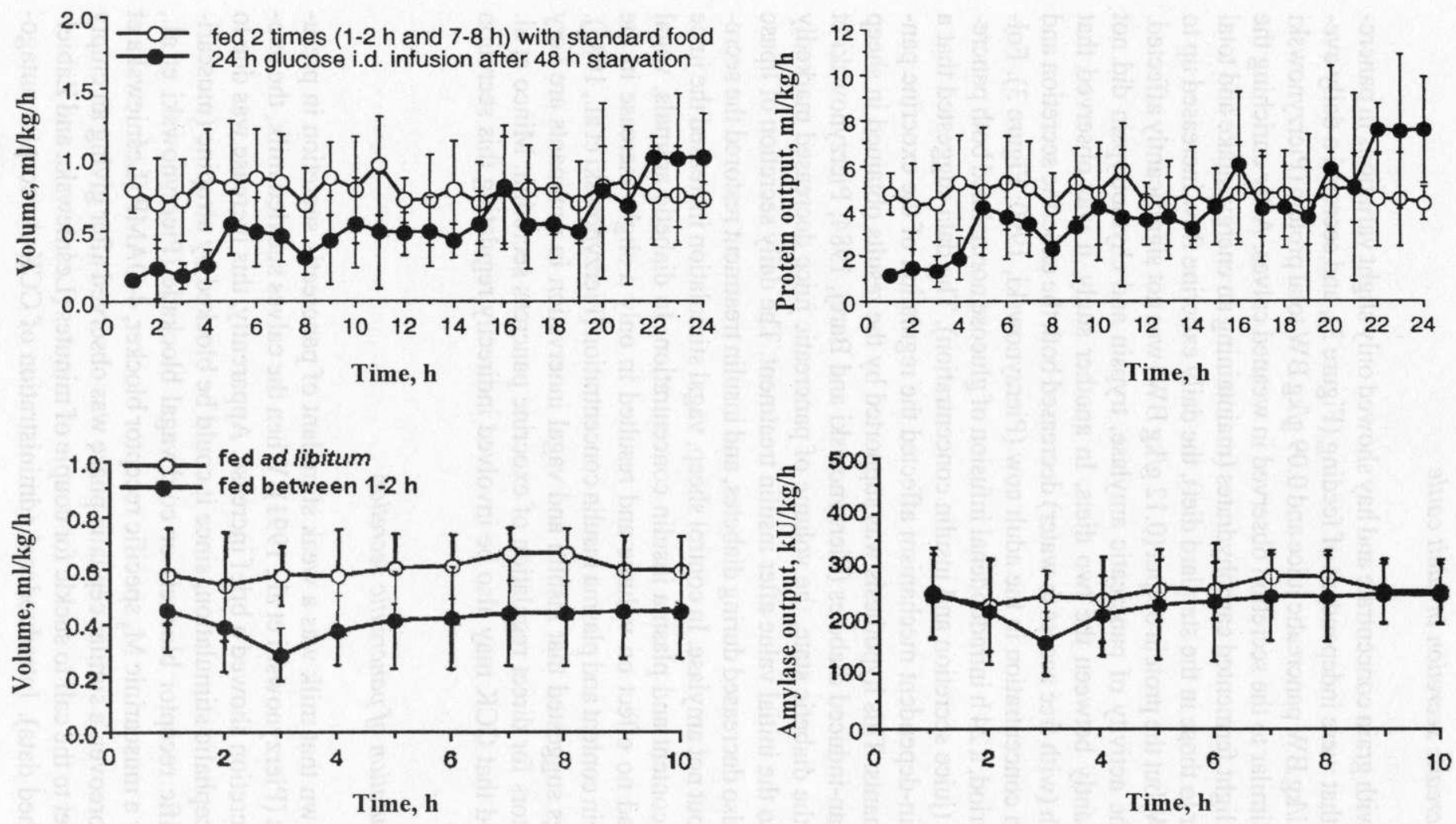

Figure 3. Lack of postprandial elevation of pancreatic secretion in adult cow (top) and sheep (bottom); pancreatic secretion even showed a decreasing tendency following feeding, this pattern was not observed in sheep fed ad libitum. Fasting for $48 \mathrm{~h}$ (top) decreased pancreatic juice secretion in dry cows, $24 \mathrm{~h}$ intraduodenal infusion of glucose normalized the secretion in the last $6 \mathrm{~h}$ of glucose infusion. Mean $\pm \mathrm{SD}$; time $0=8$ am. Adapted from Pierzynowski $(1982,1988)$ 
nist lowered the protein output during the cephalic phase (Zabielski et al., 1998) suggesting that, unlike in humans, a CCK component was involved in this response (Addler et al., 1995).

The cephalic phase of pancreatic secretion was present only in the suckling calves fed liquid feed (milk or milk replacer), and was much more evident following the morning feeding than the evening one (Zabielski et al., 1997). The cephalic phase decreased with age; the greatest responses were observed during the first month of life; they were lower but still significant in the second month (Figure 4) and not signilicant when the animals only received solid feed (Pierzynowski et al., 1991; Zabielski et al., 1997). On one hand, in ruminating calves the continuous flow of acidic digesta through the abomasum and small intestine during the preprandial period might permanently stimulate the exocrine pancreas to a certain level. Therefore, additional cephalic stimulation during solid feed ingestion could not substantially increase the secretion of juice over the already stimulated preprandial level. This was also observed in adult sheep with blocked flow of the digesta into the duodenum (Kato et al., 1984). Under these conditions, pancreatic secretion was much more stimulated by feed ingestion than it was in sheep with undisturbed digesta flow. On the other hand, it was found that giving milk to weaned calves can still produce a significant increase in pancreatic protein secretion (Figure 4) suggesting involvement of different stimulation mechanisms during suckling liquid feed and ingestion of solid feed (Leśniewska and Zabielski, unpublished observations).

Threc groups of regulating factors are possibly involved in the development of the exocrine pancreatic function in growing calves. The first one is age, which is an inherent program; the second is the digestive processes evoked by a liquid diet (milk, milk replacers), which results in a condition that is somewhat similar to that of monogastric animals (preruminant program), and the third is the digestive processes characteristic of the adult ruminant (ruminant program). Our studies indicate that the changes in pancreatic secretion observed in calves are little affected by the age of the animal, if any, and largely depend on feeding, and that the different types of feed (milk vs milk replacer in preruminant or standard diet vs diet enriched with light fermented carbohydrates in ruminant animals) may specifically affect bovine pancreatic secretion.

\section{ASSOCIATION OF THE PERIODIC PANCREATIC SECRETION WITH DUQ- DENAL MOTILITY}

In dogs, interdigestive pancreatic secretion was observed to fluctuate synchronously in phase with gastroduodenal motility (Boldyreff, 1911; DiMagno et al., 1979; Magee and Naruse 1983; Konturek et al., 1986). Feeding resulted in an 

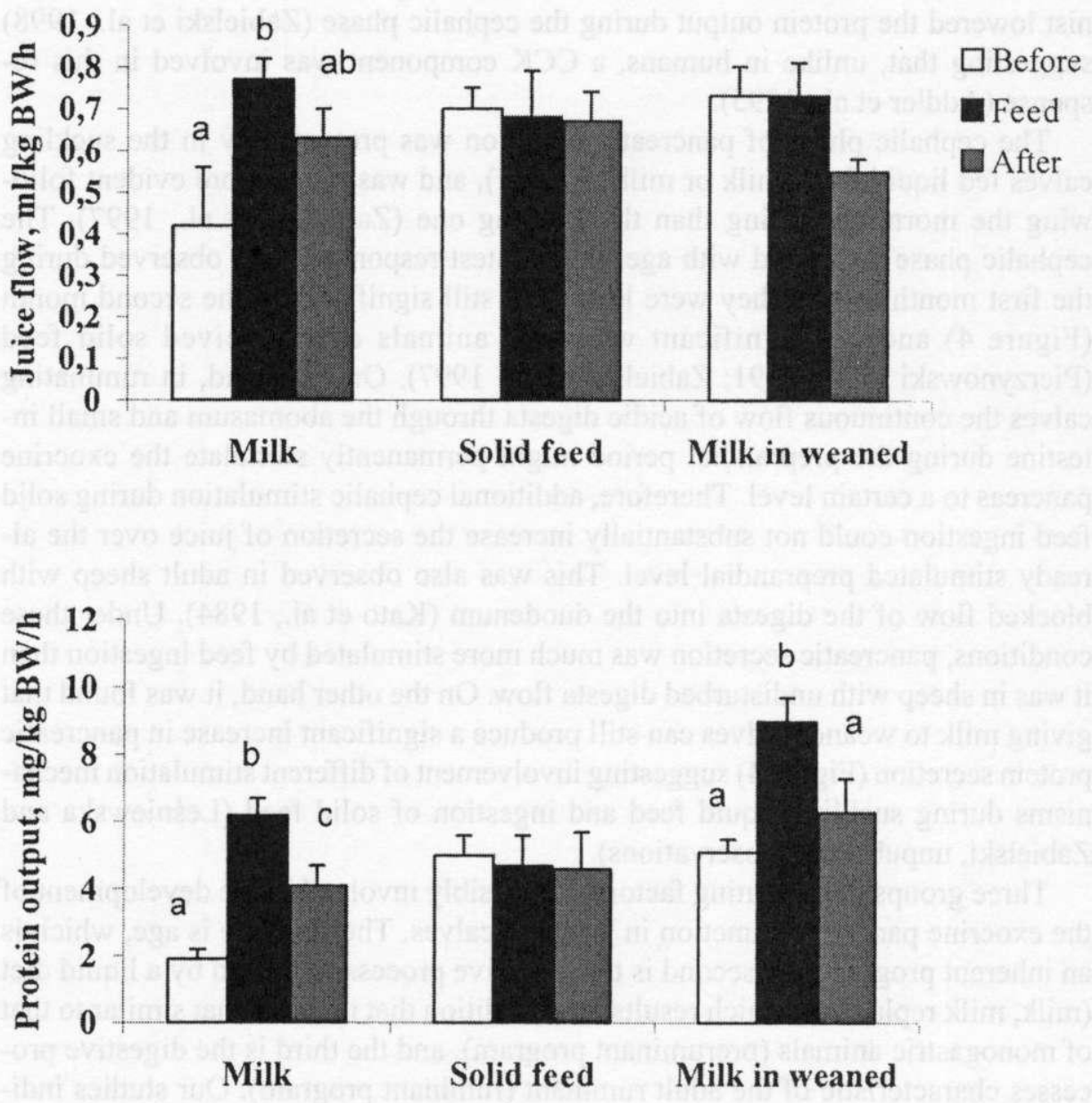

Figure 4. Effect of feed ingestion on pancreatic juice secretion in calves before and after weaning. Before weaning, the calves received milk replacer ( $3 \%$ of their body weight) to suckle. Weaned calves were fed with grain concentrate complete starter ration (daily intake of DM $950 \mathrm{~g} / \mathrm{d}$ ). The weaned calves were fed once with milk replacer ( $3 \%$ of their body weight) to examine pancreas response of weaned animal to milk stimulation. Mean + SEM pancreatic juice flow and protein output in 4 calves

interruption in the periodic secretory patterns for several hours in these animals and the patterns appeared to be influenced by the administration of exogenous gut regulatory peptides. In calves, first MMC- associated fluctuations of pancreatic juice secretion were observed starting from day 2 or 3 after birth (Zabielski and Guilloteau, unpublished data). In calves studied from the 8th day of life, duodenal 
electromyography tracings showed regular oscillations in amplitude and spike frequency similar to those observed for adult monogastric or ruminating animals (Ruckebusch and Bueno, 1973; Zabielski et al., 1993). A three-phased MMC pattern was recorded (Figure 5). In contrast to dogs, phase 4 was usually not observed in calves and phase 3 (a regular spike activity, RSA) was followed by clectrical quiescence (phase 1, no spike activity, NSA). The average duration of the duodenal MMC cycle in 8 to 30 day-old-calves was 32-34 min (Zabielski et al., 1993). In ruminant calves, the duodenal MMC lasted for $65 \mathrm{~min}$ when the pancreatic juice was reintroduced into the duodenum, and for $82 \mathrm{~min}$ when the juice was diverted (Podgurniak and Pierzynowski, 1993). Corresponding values for juice flow were 2.3 and $1.7 \mathrm{ml} / \mathrm{min}$, respectively. This allowed us to postulate a presence of feedback mechanism between the duodenal and pancreatic cycles.

In calves, pancreatic secretion (volume, bicarbonate, protein, trypsin and amylase outputs) fluctuated synchronously in phase with the duodenal electrical activity in the fasting state (Zabielski et al., 1993). The lowest volume concurred with electrical quiescence (phase 1). As a rule, secretion increased during phase 2, reached its peak just before duodenal phase 3 and waned again with the onset of phase 3 , although on rare occasions the zenith coincided with phase 3 involvement. Peaks in fluid and protein secretion were usually more than two and three times greater, respectively, than the nadir (Table 1). The periodic pancreatic secretion (PPS) was of the same duration as that of the corresponding MMCs, i.e., if a

TABLE 1

Relative change in secretory rates of individual secretory proteins and pancreatic juice flow and protein output during phases of the duodenal MMC and following feeding (mean \pm SD)

\begin{tabular}{|c|c|c|c|c|}
\hline & \multicolumn{2}{|c|}{ Interdigestive secretion } & \multicolumn{2}{|c|}{ Feeding } \\
\hline & phase 1 & phase 2 & $5+10^{\prime}$ & $25-30^{\prime}$ \\
\hline \multicolumn{5}{|l|}{ Protein Mol. Wt. } \\
\hline 97.0 & $0.11 \pm 0.05^{\mathrm{a}}$ & $0.22 \pm 0.08^{b}$ & $0.01 \pm 0.00^{\mathrm{c}}$ & $0.01 \pm 0.00^{\mathrm{c}}$ \\
\hline 76.6 & $0.53 \pm 0.04^{\text {at }}$ & $0.51 \pm 0.06^{\mathrm{a}}$ & $0.34 \pm 0.23^{\mathrm{bc}}$ & $0.38 \pm 0.05^{\mathfrak{c}}$ \\
\hline 66.8 & $0.28 \pm 0.03^{a}$ & $0.26 \pm 0.04^{\mathrm{a}}$ & $0.06 \pm 0.05^{\mathrm{b}}$ & $0.02 \pm 0.01^{b}$ \\
\hline 42.4 & $0.51 \pm 0.06^{\text {ith }}$ & $0.49 \pm 0.03^{\mathrm{a}}$ & $0.41 \pm 0.10^{\mathrm{hcc}}$ & $0.42 \pm 0.04^{c}$ \\
\hline 34.5 & $0.018 \pm 0.01$ & $0.037 \pm 0.59$ & $0.008 \pm 0.01$ & $0.013 \pm 0.01$ \\
\hline 27.9 & $1.05 \pm 0.07^{\mathrm{a}}$ & $0.79 \pm 0.10^{\mathrm{b}}$ & $0.50 \pm 0.11^{\mathrm{c}}$ & $0.57 \pm 0.05^{\mathrm{c}}$ \\
\hline 24.3 & $0.93 \pm 0.03^{a}$ & $0.95 \pm 0.04^{\mathrm{a}}$ & $0.91 \pm 0.09^{\mathrm{a}}$ & $0.76 \pm 0.07^{b}$ \\
\hline 16.6 & $0.43 \pm 0.19^{\mathrm{a}}$ & $0.64 \pm 0.12^{b}$ & $0.37 \pm 0.11^{\mathrm{a}}$ & $0.55 \pm 0.14^{\mathrm{ab}}$ \\
\hline 14.5 & $0.35 \pm 0.10^{3}$ & $0.21 \pm 0.06^{\mathrm{b}}$ & $0.33 \pm 0.08^{\mathrm{a}}$ & $0.23 \pm 0.12^{\mathrm{ab}}$ \\
\hline Juice flow, $\mu 1 / \mathrm{kg} / 5 \mathrm{~min}$ & $8 \pm 4^{a}$ & $33 \pm 10^{\mathrm{b}}$ & $70 \pm 20^{\circ}$ & $50 \pm 15^{\circ}$ \\
\hline Protein output, $\mu \mathrm{g} / \mathrm{kg} / 5 \mathrm{~min}$ & $68 \pm 57^{\text {a }}$ & $350 \pm 270^{b}$ & $1620 \pm 1140^{\circ}$ & $600 \pm 360^{b}$ \\
\hline
\end{tabular}

different letters in a row indicate statistical difference at $\mathrm{P}<0.05$ ( $\mathrm{ANOVA}$ followed by Tukey-Kramer multiple comparison test) 
MMC was prolonged then the duration of the respective PPS lengthened. SDSPAGE electrophoresis of bovine pancreatic juice revealed significant variations in the number of detectable proteins in phase with the PPS cycle. There were only 17 bands detected during the secretory trough and 21 bands during the secretory peak (Leśniewska et al., 1999). In addition to that, the relative amount of several proteins (expressed as a trace density in electrophoregram) showed regular ups and downs in phase of the PPS cycle (Table 1) indicating that there is no parallel secretion of pancreas enzymes in the interdigestive period in calves.

The duodenal MMC and PPS have been observed in neonatal and ruminating calves (Zabielski et al., 1993, 1997) and in adult sheep (Onaga et al., 1996). The duration of MMC and PPS in calves was very short in comparison with the nearly $2 \mathrm{~h}$ cycle observed in the adult dog and human, although similar in duration to that recorded in human term infants (Berseth, 1989). The duration of the duodenal MMC and PPS cycles showed a tendency to increase with age in calves fed only liquid feed; in calves 10-16 days of age it was about $32 \mathrm{~min}$, while in those 36-45 days of age, $40 \mathrm{~min}$ (Zabielski et al., 1994). In preruminant calves, the pattern of pancreatic secretion displayed a shortening in the cycle of the nadir secretion with age. In adult sheep, the PPS was manifested as a temporary drop in secretion concomitant with phase 1 and having no clear peak during phase 2 . A change in the diet from liquid to solid feed significantly increased the duration of the duodenal MMC (Ruckcbusch and Bueno, 1973; Zabielski et al., 1997) and PPS cycles (Podgurniak and Pierzynowski, 1993; Zabielski et al., 1997) in calves.

These results show that both in young and in adult ruminants the flow of pancreatic juice is not constant but periodically oscillates in concert with the duodenal motor/electrical activity, with a pattern resembling that previously described for monogastric animals. However, in calves the amplitude of the oscillations in the pancreatic secretion are smaller and the length of the cycles is noticcably shorter than in dogs. The cycles change with the development of the digestive tract in calves.

Insulin levels in fasting calves showed short-lasting oscillations (amplitude 1-9 $\mu \mathrm{U} / \mathrm{ml}$, duration 6-8 $\mathrm{min}$ ) in blood plasma which did not correspond to fasting MMC and PPS. However, after reproducing postprandial glucaemia by the intravenous infusion of glucose, plasma insulin started to fluctuate in phase with MMC and PPS, and the timing of the duodenal and pancreatic endocrine and exocrine events then became surprisingly regular (Kiela et al., 1994). In calves fed with milk replacer based on milk and soya bean protein, the concentration of plasma secretin was significantly higher in phase 2 than in phase 1 of MMC (Zabielski ct al., 1994), and the secretin concentration in the peripheral blood plasma showed periodic oscillations well harmonized with those of MMC and PPS. However, the CCK concentration remained stable throughout the PPS cycle in these animals. In preruminant calves fed with milk replacer based on milk 




Figure 5. A representative recording of a three-phased $\mathrm{MMC}$ in the duodenum and a secretion of pancreatic juice in a 6 week-old calf. E1, E2, and E3 on-line frequency analysis of myoelectrical activity from the proximal and mid-duodenum (SPM, spikes per minute). The interdigestive pancreatic secretion recorded by a photoelectric drop counter fluctuates in phase with the duodenal MMC. The lowest secretion is observed just after the phase 3 of MMC and the highest during late phase 2 of MMC. Feeding with $3 !$ milk replacer (black bar) disturbed the MMC and PPS pattern, and transiently increased the pancreatic secretion. The PPS reappeared together with the duodenal MMC

powder, however, there was significant fluctuation of plasma CCK as well as PP, somatostatin and motilin in phase with the MMC in addition to secretin fluctuations. However, the fluctuations of plasma gut regulatory peptides were minimalised or abolished when the calves were switched to milk replacer based on hydrolyzed fish protein suggesting that the protein source play an important role in gut endocrine function (Zabielski et al., 1998). In fasting dogs, no fluctuations in secretin and CCK have been observed, and possible changes in gastrin levels were somewhat controversial. However, motilin and PP clearly fluctuated in concert with PPS (Konturek et al., 1986) in dogs, while in pigs cyclical variations were found in the plasma concentrations of all of the above-mentioned peptides (Cuber et al., 1985, $1986 \mathrm{a}, \mathrm{b}$ ). The physiological role of gut regulatory peptide fluctuations in calves has not yet been determined, although they may be involved in the feedback regulation of gastric activity, regulation of the length of the duodenal MMC or the modulation of pancreatic periodic peaks, but they are rather not involved in the generation of gastrointestinal motor and pancreatic periodic activities (Zabielski et al., 1995, 1998).

It has been shown that duodenal mechanical activity is temporally coordinated with electrical activity (Zabielski ct al., 1993), and studies using electromagnetic 
flow probes implanted in the duodenum of preruminant calves (Girard and Sissons, 1992) demonstrated that the duodenal MMC was synchronized with the rate of digesta flow. During phase 1, the digesta flow was halted, and the maximal flow was observed just before phase 3 . Finally, a positive correlation between the number of spikes/phase in the duodenum, the blood plasma secretin concentration, and the pancreatic secretion (volume, and protein output) in the MMC/PPS cycles was found in these animals (Leśniewska et al., 1996). Therefore, in calves, the pancreatic juice appears to be secreted in harmony with duodenal function in a precisely regulated manner from an early stage of life.

\section{POSTPRANDIAL PANCREATIC SECRETION IN TERMS OF BIOLOGICAL RHYTHMS}

In the adult sheep or cow, there is a negligible or nonexistent increase in pancreatic secretion following feed ingestion (Picrzynowski et al., 1988; Croom et al., 1992), while in dogs (Konturek et al., 1986) and in preruminant calves (Pierzynowski et al., 1992) feeding stimulates both pancreatic juice and enzyme secretion. However, there is a considerable difference between dogs and calves in their postprandial responses. In dogs, the duodenal three-phased MMC is replaced or masked by a continuous ,feeding pattern", and pancreatic postprandial response is characterized by a complete disruption of the PPS for several hours. At this time pancreatic sccretion shows three subsequent elevations: the cephalic, gastric and intestinal phases. When the stomach and intestines become empty, the canine PPS reappears together with the duodenal MMC. In preruminant calves fed milk replacer, the MMC and PPS disappear postprandially for less than $2 \mathrm{~h}$ and then reappear, despite the presence of digesta in the small intestine (Zabiclski ct al,, 1993). Only the vagally dependent cephalic phase is present in preruminant calves, but the two next phases (gastric and intestinal) are not observed (Zabiclski et al., 1997). The duration of the first few postprandial cycles of PPS and MMC in preruminant calves is prolonged by about $15 \mathrm{~min}$. To date, the postprandial characteristics of the PPS in adult ruminants have not been studied in detail. Nevertheless, preliminary electromyography studies have shown only a prolonged duration of the duodenal MMC, without any disrupting periodic fluctuations of the upper gut, after the ingestion of feed in cows and sheep (Ruckebusch and Bueno, 1973; Bueno ct al., 1975). These findings agree with our results showing that the PPS and MMC persist following feeding in ruminating calves. Thus in cattle, regardless of age, MMC and PPS are actively involved in the digestive processes, similar to that occurring in pigs fed ad libitum (Kiela et al., 1996; Leśniewska et al., 1998), whereas in dogs MMC and PPS appear to play the role of a ,housekeeper”, important only during the interdigestive period. 


\section{REGULATION OF PANCREATIC FUNCTION IN CALVES}

\section{Vagal innervation-dependent regulatory mechanisms}

The vagal nerves appear to play a more important role in the regulation of exocrine pancreatic secretion in preruminant calves than in dogs. In calves, the vagal and cholinergic pathways appear to dominate all the regulatory mechanisms of pancreatic juice secretion and there are many similarities to the mechanisms found in humans (Addler et al., 1995). Vagi are responsible for the generation of the periodic pancreatic activity in calves since atropine and 4-DAMP can completely block this activity, and cold vagal blockade can almost completely block the periodic pancreatic fluctuations (Zabielski and Naruse, 1999). The cephalic phase of pancreatic secretion is also entirely abolished by means of these blockades, as are the pancreatic responses to intraduodenal stimulation with soya bean extract and hydrochloric acid (Zabielski et al., 1992). It has also been shown that the action of secretin and CCK on the secretion of pancreatic juice is vagally dependent. The effect of secretin is blocked and that of CCK markedly decreased by cold vagal blockade (Zabiclski et al., 1992). Normal responses to secretin and CCK reappear soon after the vagi are rewarmed.

\section{Local reflexes}

Local duodeno-pancreatic reflexes regulate the amount of secreted pancreatic juice but appear to be less relevant regulators of the periodic activity of the exocrine pancreas in calves. Duodenal perfusion with lidocaine and intraduodenal installation of capsaicin did not abolish the PPS cycles but decreased secretion per cycle and the response to intraduodenal $\mathrm{HCl}$ stimulation (Zabielski et al., 1994). Diversion of the gastroduodenal contents produced similar effects. These effects were considerably weaker than those of the cold vagal blockade. These findings differed slightly from those in the dog by Chen et al. (1983). Experiments in adult sheep and cows (Magee, 1961; Pierzynowski et al., 1988) showed that in contrast to the situation in preruminant calves, the $\mathrm{pH}$ of the duodenal contents and the duodenal digesta flow are essential regulators of pancreatic secretion. Therefore, we suggest that the local reflexes are present but immature in preruminant calves and develop thereafter. Possibly the limiting factor in these calves is an immaturity of the GI tract endocrine system involving quantitative/qualitative changes in the endocrine cell function and receptors for gut regulatory peptides.

\section{Involvement of gut regulatory peptides in neuro-hormonal regulation}

Gut regulatory peptides are important means controlling the exocrine pancreas function in mammals. Gastrin is a newly proposed stimulator that may act both via 
a CCK-A and CCK-B/gastrin receptors (LeDrean et al., 1999). In contrast to gastrin, $\mathrm{CCK}$ and secretin are well-established stimulators of pancreatic juice secretion, and PP and somatostatin - inhibitors. Other peptides were also investigated (e.g., VIP, PACAP, motilin) but their effects on the calf exocrine pancreas seem to be less relevant (Zabielski and Naruse, 1999). These peptides apparently work in calf neonates, but the results of our studies suggest more complex mechanisms that are mostly indirect, i.e., not related to the specific receptors located on the pancreatic acinar cells. At least in the case of CCK, secretin and VIP the intermediation of vagal nerves has been demonstrated (Zabielski et al., 1992, 1994). In the case of CCK, besides having a direct receptoral effect on pancreatic acinar cells, an indirect duodenal-mucosa-located mechanism that controls pancreatic juice secretion via a long vago-vagal reflex has been found in preruminant calves ( $\mathrm{Za}$ bielski et al., 1995, 1998). These suggestions are compatible with recent findings in pigs (Kicla et al., 1996) and in rats (Li and Owyang, 1992). Recent studies in preruminant calves demonstrated luminal release of CCK that depend on vagal stimulation (Zabielski et al., 1999) as well as confirmed the results of Blackshaw and Grundy (1990) on the presence of functional CCK-A receptor on afferent nerve terminals in the small intestinal mucosa (Morisset et al., unpublished data). Consequently, intraduodenal administration of non-absorbable CCK-A receptor antagonist reduces the secretion of pancreatic juice, and intraduodenal administration of CCK stimulates the secretion of pancreatic juice in a dose-related manner. The latter effect was abolished by atropine (Zabielski et al., 1998). In our experiments we did not observe significant elevation in plasma CCK (Zabiclski and Kato, unpublished data) following feeding or intraduodenal administration of soya bean extract in preruminant calves. Plasma CCK increased, however, following intraduodenal infusion of $\mathrm{HCl}$ or $\mathrm{CCK}-\mathrm{A}$ receptor antagonist and intravenous infusion of atropine (Zabielski et al., 1992, 1995, 1998). Our radioimmunoassay results agreed with those of Furuse et al. (1991) but not those of Guilloteau et al. (1992) and Toullec et al. (1992), who reported a doubling in the CCK plasma concentration following feed ingestion.

In conclusion, it seems that gut regulatory peptides may stimulate pancreatic secretion via a direct mechanism, i.e., via their receptors on pancreas acini as well as via an indirect mechanism located in the duodenal mucosa. The concentration of gut regulatory peptides in the peripheral blood does not reflect their physiological relevance in controlling pancreatic exocrine secretion. The indirect mechanism involves the vagal afferent fibres and a dorsal vagal complex (Deng and Whitcomb, 1998). The local duodenal mechanism seems to be of physiological relevance in preruminant calves. Bearing in mind the above information, we suggest that any pathological process in the small intestinal mucosa may seriously affect the regulation of pancreatic secretion and in turn influence the digestion processes that depend on the presence of pancreas juice in the lumen of the small intestine. 


\section{REFERENCES}

Addler G., Nelson D.K., Katschinski M., Beglinger C., 1995. Neurohormonal control of human pancreatic exocrine secretion. Pancreas 10,1-13

Berseth C.L., 1989. Gestational evolution of small intestine motility in preterm and term infants. J. Pediat. 115, 646-651

Blackshaw L.A., Grundy D., 1990. Effects of cholecystokinin (CCK-8) on two classes of gastroduodenal vagal afferent fibre. J. Autonom. Nerv. Syst. 31, 191-202

Boldyreff W., 1911. Einige neue Seiten der Tatig des Pancreas. Ergebn. Physiol. 11, 121-217

Bucno L., Fioramonti J., Ruckebusch Y., 1975. Rate of flow of digesta and electrical activity of the small intestine in dogs and sheep. J. Physiol. 249,69-85

Chen M.H., Joffe S.N., Magec D.F., Murphy R.F., Naruse S., 1983. Cyclic changes of plasma pancreatic polypeptide and pancreatic secretion in fasting dogs. J. Physiol. 341, 453-461

Chey W.Y., 1991. Regulation of pancreatic exocrine secretion. Int. J. Pancreatol. 9, 7-20

Croom W.J., Bull L.S., Taylor I.L., 1992. Regulation of pancreatic exocrine sccretion in ruminants: a review. J. Nutr. 122, 191-202

Cuber J.C., Bemard C., Laplace J.P., Chayvialle J.A., 1985. Comparative assessment of secretin and motilin responses to graded duodenal acidification in anacsthetized pigs. Digestion 32, 35-41

Cuber J.C., Bernard C., Laplace J.P., Levenez F., Chayvialle J.A., 1986a. Plasma cholecystokinin like immunoreactivity varies cyclically during the migrating nyoelectric complexes in the pig. Can. J. Physiol. Pharmacol. 64, 45

Cuber J.C., Laredo C., Laplace J.P., Chayvialle J.A., 1986b. Autocovariance analysis of plasma motilin, pancreatic polypeptide, somatostatin and gastrin levels during the migrating myoelectric complex (MMC) sequence in the conscious pig. In: Proceedings of $3^{\text {rd }}$ European Sympsium on Gastrointestinal Motility, Bruges, Abstr. 32

Deng X., Whitcomb D.C., 1998. Neurohormonal control of the exocrine pancreas. Curr. Opin. Gastroen. 14, 362-368

DiMagno E.P., Hendricks J.C., Go V.L.W., Dozois R.R., 1979. Relationships among canine fasting pancreatic and biliary secretions, pancreatic duct pressure, and duodenal phase III motor activity - Boldyreff revisited. Digest. Dis. Sci. 24, 689-693

Furuse M., Yang S.I., Choi Y.H., Kawamura N., Takahashi A., Okumura J., 1991. A note on plasma cholecystokinin concentration in dairy cows. Anim. Prod. 53, 123-125

Girard C.L., Sissons J.W., 1992. The role of migrating myoelectric complexes in the regulation of digesta transport in the preruminant calf. Can. J. Physiol. Pharmacol. 70, 1142-1147

Guilloteau P., Chayvialle J.A., Toullec R., Grognet J.F., Bernard C., 1992. Early-life patterns of plasma gut regulatory peptides levels in calves: effects of the first mea!s. Biol. Neonate 61 , 103-109

Kato S., Onaga T., Zabielski R., Leśniewska V., Guilloteau P., 1999. Characteristics of in vivo and in vitro experimental modełs. In: S.G. Pierzynowski, R. Zabielski (Editors). Biology of the Pancreas in Growing Animals. Elsevier, Amsterdam, pp. 89-122

Kato S., Usami M., Ushijima J., 1984. The effect of feeding on pancreatic exocrine secretion in sheep. Jpn. J. Zootech. Sci. 55, 973-977

Kieła P., Leśniewska V., Picrzynowski S.G., Zabiclski R., 1996. Temporal coordination between cxocrine pancreatic secretion and antroduodenal myoelectric activity in pigs. The effect of feeding. Digestion 57, Suppl. 4, 241 (Abstr.)

Kicla P., Zabielski R., Mineo H., Onaga T., Kato S., Barej W., 1994. Plasma insulin fluctuates in phase with the exocrine pancreatic secretion and duodenal MMC during constant glucose infusion in the neonatal calf. Proc. Soc. Nutr. Physiol. 3, 296 (Abstr.) 
Kiela P., Zabiclski R., Podgurniak P., Midura M., Barej W., Gregory P.C., Pierzynowski S.G., 1996. Cholecystokinin- 8 and vasoactive intestinal polypeptide stimulate exocrine pancreatic secretion via duodenal mediated mechanisms in the conscious pig. Exp. Physiol. 81, 375-384

Konturek S.J., Thor P.J., Bilski J., Bielański W., Laskiewicz J., 1986. Relationships between duodenal motility and pancreatic sccretion in fasted and fed dogs. Amer. J. Physiol. 250, G570-G574

Le Dréan G., Le Huërou-Luron I., Gestin M., Desbois C., Romé V., Bernard C., Dufresne M., Moroder L., Gully D., Chayvialle J.A., Fourmy D., Guilloteau P., 1999. Exogenous CCK and gastrin stimulate pancreatic exocrine secretion via CCK-A but also CCK-B/gastrin receptors in the calf. Eur. J. Physiol, 438, 86-93

Le Meuth V., Philouze-Rome V., Le Huërou-Luron I., Formal M., Vaysse N., Gespach C., Guilloteau P., Fourmy D., 1993. Differential expression of A- and B-subtypes of cholecystokinin/gastrin receptors in the developing calf pancreas. Endocrinology 133,1182-1191

Leśniewska V., Ceregrzyn M., Picrzynowski S.G., Zabielski R., 1996. Effect of $M_{3}$ muscarinic antagonist (4-DAMP) administration on non-stimulated and cholecystokinin-8 stimulated secretion of pancreatic juice and duodenal motility in conscious calves. Regul. Peptides 64, 108 (Abstr.)

Leśniewska V., Kiela P., Kato S., Zabielski R., 1996. Periodic pancreatic secretion correlates with phases of duodenal migrating myoelectric complex and plasmal secretin in calves. J. Physiol. Pharmacol. 47, Suppl. 2, 98 (Abstr.)

Leśniewska V., Pierzynowski S.G., Johansen H.N., Jensen M.S., Jensen B.B., 1998. Weaning of pigs: duodenal myoelectrical activity during the change from sow's milk to solid feed. J. Anim. Feed Sci. 7, Suppl. 1, 267-270

Leśniewska V., Płoszaj T., Barej W., Zabielski R., 1999. Periodic pattern of secretion of pancreatic juice proteins in new-born calves demonstrated by SDS-page electrophoresis. In: S.G. Pierzynowski, R. Zabiclski (Editors). Biology of the Pancreas in Growing Animals. Elsevicr, Amsterdam, pp. 139-149

Li Y., Owyang C., 1992. Cholecystokinin at physiologic levels stimulates pancreatic enzyme secretion via an afferent vagal pathway originating from the duodenum. Regul. Peptides 40, Suppl. 2 , 196 (Abstr.)

Magee D.F., 1961. An investigation into the external secretion of the pancreas in sheep. J. Physiol. $158,132-143$

Magee D.F., Naruse S., 1983. Neural control of periodic secretion of the pancreas and the stomach in fasting dogs. J. Physiol. 344, 153-160

McCormick R.J., Stewart W.E., 1967. Pancreatic secretion in the bovine calf. J. Dairy Sci. 50, 568-571

Mineo H., lwaki N., Kogishi K., Zabielski R., Onaga T., Kato S., 1995. Effects of intravenous infusions of cholecystokinin (CCK)-8 on exocrine and endocrine pancreatic secretion in conscious sheep. Comp. Biochem. Physiol. Pt.A 111, 133-138

Onaga T., Uchida M., Kimura M., Miyazaki M., Mineo H., Kato S., Zabiclski R., 1996. Effect of pituitary adenylate cyclase-activating polypeptide on exocrine and endocrine secretion in the ovine pancreas. Comp. Biochem. Physiol. Pt.C 115, 185-193

Pierzynowski S.G., 1982. Conjugated effects of feeding and hormones on secretion of pancreatic juice in sheep. PhD Thesis, Department of Animal Physiology, Faculty of Veterinary Medicine, Warsaw Agricultural University, Poland

Picrzynowski S.G., 1990. The effect of fasting and subsequent long-term intraduodenal glucose infusion on the exocrinc pancreas secretion in cattle. J. Anim. Physiol. Anim. Nutr. 63, 198-203

Pierzynowski S.G., Barej W., 1984. The dependence of exocrine pancreatic secretion on insulin in shecp. Quart J. Exp. Physiol. 69, 35-39 
Pierzynowski S.G., Barej W., Mikołajczyk M., Zabielski R., 1988. The influence of light fermented carbochydrates on the exocrine pancreatic secretion in cows. J. Anim. Physiol. Anim. Nutr. 60 , 234-238

Pierzynowski S.G., Podgurniak P., Mikołajczyk M., Szczesny W., 1986. Insulin and the parasympathetic dependence of pancreatic juice secretion in healthy and alloxan diabetic sheep. Quart. J. Exp. Physiol. 71, 401-407

Pierzynowski S.G., Weström B.R., Svendsen J., Svendsen L., Karlsson B.W., 1995. State-of-the-art. Development and regulation of porcine pancreatic function. Int. J. Pancreatol. 18, 81-94

Picrzynowski S.G., Zabielski R., Podgurniak P., Kicla P., Sharma P., Weström B.R., Kato S., Barej W., 1992. Effects of reversible cold vagal blockade and atropinization on exocrine pancreas function during liquid feed consumption in calves. J. Anim. Physiol. Anim. Nutr. 67, 268-273

Pierzynowski S.G., Zabielski R., Weström B., Mikolajczyk M., Barej W., 1991. Development of the exocrine pancreatic function in chronically cannulated calves from the preweaning period up to carly rumination. J. Anim. Physiol. Anim. Nutr. 65, 165-172

Podgurniak P., 1987. A simple method for the cold blockade of vagal conductivity in chronic experiment. Acta Physiol. pol. 38, 159 (Abstr.)

Podgurniak P., Pierzynowski S.G., 1993. Relation between the electrical activity of the duodenum and pancreatic juice secretion in calves. Chin. Med. Sci. J. 8, 75 (Abstr)

Rao R.K., Pepperl S., Porreca F., 1995. Tonic suppression of gastric acid secretion by endogenous peptides in neonatal rats. Amer. J. Physiol. 269, G721-G728

Routley E.F., Mann F.C., Bollman J.L., Grindlay J.H., 1952. Effects of vagotomy on pancreatic secretion in dogs with chronic pancreatic fistula. Surg. Gynecol. Obstet. 95, 529-536

Ruckebusch Y., 1989. Gastrointestinal motor functions in ruminants. In: S.G. Shultz (Editor). Section 6: Handbook of Physiology, The Gastrointestinal System, Vol 1: Motility and Circulation, Part 2. Oxford University Press, New York, pp. 1225-1282

Ruckebusch Y., Bueno L., 1973. The effect of weaning on the motility of the small intestine in the calf. Brit. J. Nutr. 30, $491-499$

Ruckebusch Y., Dardillat C., Guilloteau P., 1983. Development of digestive functions in the newborn ruminant. Ann. Rech. Vet. 14, 360-374

Ternouth J.H., Buttle H.L., 1973. Concurrent studies of the flow of digesta in the duodenum and of exocrine pancreatic secretion of calves. The collection of the exocrinc pancreatic secretion from a duodenal cannula. Brit. J. Nutr. 29, 387-397

Toullec R., Chayvialle J.A., Guilloteau P., Bernard C., 1992. Early-life patterns of plasma gut regulatory peptide levels in calves. Effects of age, weaning and feeding. Comp. Biochem. Physiol. 102A, 203-209

Toullec R., Guilloteau P., Le Huërou-Luron 1., 1994. Postprandial development of endocrine intestine functions in young ruminants. In: W. Barej, R. Zabielski, P. Ostaszewski (Editors). The Developing of Digestive and Metabolic Processes in New Born and Growing Ruminants. Proceedings of Satelite Symposium to VIII ISRP. Fundacja Rozwój SGGW, Warsaw (Poland), pp. 9-20

Wass W.M., 1965. The ducts systems of the bovine and porcine pancreas. Amer. J. Vet. Res. 26, 267-272

Xu R-J., 1998. Bioactive peptides in milk and their biological and health implications. Food Rev. Int. 14, $1-16$

Yokota C., Kawai K., Ohashi S., Watanabe Y,, Suzuki S., Yamashita K., 1993. Stimulatory effects of pituitary adenylate cyclase-activating polypeptide (PACAP) on insulin and glucagon release from the isolated perfused rat pancreas. Acta. Endocrinol. 12, 473-479

Zabielski R., 1998. Regulatory peptides in milk, food, and in the gastrointestinal lumen of young animals and children. J. Anim. Feed Sci. 7, Suppl. 1, 65-78 
Zabielski R., Dardillat C., Le Huërou-Luron I., Bernard C., Chayvialle J.A., Guilloteau P., 1998. Periodic fluctuations of gut regulatory peptides in phase with the duodenal migrating myoelectric complex in preruminant calves: effect of different sources of dietary protein. Brit. J. Nutr. 79 , 287-296

Zabielski R., Kato S., Pierzynowski S.G., Minco H., Podgurniak P., Barej W., 1992. Effect of intraduodenal $\mathrm{HCl}$ and soybean extract on pancreatic juice secretion during atropinization and cold vagal blockade in calves. Exp. Physiol. 77, 807-817

Zabielski R., Kiela P., Kato S., Barej W., 1996. Effect of intraduodenal hydrochloric acid on pancreatic juice secretion in preruminant calves. J. Physiol. Pharmacol. 47, Suppl. 2, 106 (Abstr.)

Zabielski R., Kiela P., Leśniewska V., Krzeminiski R., Mikołajczyk M., Barej W., 1997. Periodic pancreatic secretion in phase with duodenal migrating myoelectric complex investigated over $24 \mathrm{~h}$ in preruminant and ruminant calves. Brit. J. Nutr. 78, 427-442

Zabielski R., Kiela P., Onaga T., Mineo H., Gregory P.C., Kato S., 1995. Effect of neural blockades, gastrointestinal regulatory peptides and diversion of gastroduodenal contents on periodic pancreatic secretion in the preruminant calf. Can. J. Physiol. Pharmacol. 73, 1616-1624

Zabielski R., Kiela P., Onaga T., Mineo H., Kato S., Barej W., 1994. Vagal nerve is a main regulator of periodic pancreatic secretion in the preruminant calf. Proc. Soc. Nutr. Physiol. 3, 93 (Abstr.)

Zabiclski R., Kicla P., Podgurniak P., Gregory P.C., Picrzynowski S.G., 1999. Cholecystokinin-like activity in the duodenal lumen of anaesthetized neonatal calves. Pol. J. Vet. Sci. 2, 13-17

Zabiclski R., Kiela P., Podgurniak P., Pierzynowski S.G., 1996. Cholecystokinin in the duodenal lumen of newborn calves. Digestion 57, Suppl. 4, 278-279

Zabielski R., I.cśniewska V., Borlak J., Gregory P.C., Kiela P., Pierzynowski S.G., Barej W., 1998. Effects of intraduodenal administration of tarazepide on pancreatic secretion and duodenal EMG in neonatal calves. Regul. Pept. 78, 113-123

Zabielski R., Naruse S., 1999. Neurohormonal regulation of the exocrine pancreas during postnatal development. In: S.G. Pierzynowski, R. Zabiclski (Editors). Biology of the Pancreas in Growing Animals. Elsevier, Amsterdam, pp. 151-192

Zabiclski R., Onaga T., Mineo H., Kato S., 1992. Effects of peripheral and local VIP administration on secretion of cxocrine pancreas and on electrical and mechanical activity of duodenum in preruminating calves. Biomed. Res. 13, Suppl. 2, 243-246

Zabielski R., Onaga T., Mineo H., Kato S., 1993. Periodic fluctuations in pancreatic secretion and duodenal motility investigated in neonatal calves. Exp. Physiol. 78, 675-684

Zabiclski R., Onaga T., Mineo H., Kato S., 1994. Exocrine pancreatic responses to CCK-8 and VIP infused during NSA and RSA phase of duodenal MMC in calves - does pancreatic responsiveness to GI peptides fluctuate periodically? Biomed. Res. 15, Suppl. 2, 371-375

Zabiclski R., Onaga T., Mineo H., Kato S., Pierzynowski S.G., 1995. Intraduodenal cholecystokinin octapeptide (CCK-8) can stimulate pancreatic secretion in the calf. Int. J. Pancreatol. 17, 271-278

Zabielski R., Onaga T., Minco H., Okine E., Kato S., 1994. Pituitary adenylate cyclase acticating polypeptide (PACAP) stimulates exocrinc pancreas in conscious preruminating calves. Comp. Biochem. Physiol. Pt.C 109, 93-99

Zabielski R., Onaga T., Minco H., Pierzynowski S.G., Kato S., 1994. Local versus peripheral blood administration of cholecystokinin- 8 and secretin on pancreatic secretion in calves. Exp. Physiol. $79,301-311$

Zabielski R., Pierzynowski S.G., Podgumiak P., Barej W., 1992. Elfect of secretin and cholecystokinin octapeptide (CCK8) on exocrine pancreas during cold vagal blockade in calves. J. Anim. Physiol. Anim. Nutr. 67, 173-180 
Zabielski R., Podgurniak P., Pierzynowski S.G., Barej W., 1990. Exocrine pancreatic function during cold blockade of the vagus in chronic experiments on calves. Exp. Physiol. 75, 401-406

Zabielski R., Terui Y., Onaga T., Mineo H., Kato S., 1994. Plasma secretin fluctuates in phase with pancreatic periodic secretion and duodenal migrating nyoelectric complex in calves. Res. Vet. Sci. $56,332-337$

\section{STRESZCZENIE}

\section{Rozwój i regulacja wydzielania soku trzustkowego u bydla. State-of-the-art}

Artykuł jest podsumowaniem cyklu badań nad wydzielaniem soku trzustkowego u cicląt $w$ wieku od pierwszych dni po urodzeniu do osiagnięcia pełnego stanu rozwoju przedżoładków oraz u osobników dorosłych. Cykliczne wahania wydziclania soku trzustkowego zsynchronizowane w fazie $z$ wędrującym kompleksem mioelektrycznym obserwowano u cicląt od 2-3 dnia życia. Zjawisko to rozwijało się wraz z dojrzewaniem funkcji przewodu pokarmowego. U dorosłych krów wydzielanie soku trzustkowego nie ulegało tak wyraźnym cyklicznym wahaniom i nie było stymulowane pokarmem. Zmiana diety powodowała jednak istotne zmiany w wielkości średnicj dobowej sekrecji, która w dużym stopniu była zalcżna od funkcjonowania osi insulinowo-pęcherzykowej trzustki. W drugiej części artykułu omówiono rolę nerwów błędnych, żołądkowo-jelitowych peptydów regulacyjnych i składników treści pokarmowej dwunastnicy w regulacji wydzielania soku trzustkowego u cieląt. Przedstawiono mechanizm oddziaływania peptydów regulacyjnych na trzustkę wprost z micjsca ich uwalniania, tzn. zc śluzówki dwunastnicy, w której unerwienie blędne pełni bardzo ważną rolę pośredniczącą. 